\title{
ANALISIS DEIKSIS PERSONA, WAKTU DAN TEMPAT PADA PEMBELAJARAN DARING (DALAM JARINGAN) MATA KULIAH BAHASA INDONESIA
}

\section{Eka Rihan K}

STAIN Sultan Abdurrahman Kepulauan Riau, Indonesia

Email: ekarihank@gmail.com

\begin{abstract}
This study aims to describe the form and function of online learning deixis (in network) Indonesian language courses at STAIN Sultan Abdurrahman, Riau Islands. Qualitative descriptive research method. Technique data collection techniques see. The data validity technique is triangulation of sources of the online learning process in the form of interactions between lecturers and students in Whatsapp groups. Interactive model data analysis techniques consist of data collection, data reduction, data presentation, and conclusion drawing. The results of online learning research were in the form of personal deixis, time deixis and place deixis. Dominant persona deixis uses more pronouns $I$, he, we, we, them as singular first person, third singular, first plural, and third plural deixis, in the context of online learning, and dominant person deixis appears more than place and third person deixis. time deixis. One of the functions of this person, place and time deixis is to clarify the reference information for personal deixis, the place and time when the speaker speaks according to the context of the situation and conditions that occur when online learning takes place.
\end{abstract}

Keywords: deixis; online learning; indonesian

\begin{abstract}
Abstrak
Penelitian ini bertujuan untuk mendeskripsikan bentuk dan fungsi deiksis Pembelajaran Daring (Dalam Jaringan) Mata Kuliah bahasa Indonesia di STAIN Sultan Abdurrahman Kepulauan Riau. Metode penelitian deskriptif kualitatif. Teknik pengumpulan data teknik simak. Teknik keabsahan data triangulasi sumber proses pembelajaran daring berupa interaksi antara dosen dan mahasiswa dalam Grup Whatsapp. Teknik analisis data model interaktif terdiri dari pengumpulan data, reduksi data, penyajian data, dan conclusion drawing. Hasil penelitian pembelajaran daring berupa deiksis persona, deiksis waktu dan deiksis tempat. Deiksis persona dominan lebih banyak menggunakan kata ganti saya, dia, kami, kita, mereka sebagai kata ganti orang pertama tunggal, ketiga tunggal, pertama jamak, dan ketiga jamak, dalam konteks pembelajaran daring, dan deiksis persona dominan lebih banyak muncul daripada deiksis tempat dan deiksis waktu. Fungsi dari deiksis persona, tempat dan waktu ini salah satunya yaitu untuk memperjelas keterangan rujukan deiksis persona, tempat dan waktu ketika penutur bertutur sesuai konteks situasi dan kondisi yang terjadi saat pembelajaran daring berlangsung.
\end{abstract}


Kata kunci: deiksis; pembelajaran daring; bahasa indonesia.

\section{Coresponden Author}

Email: ekarihank@gmail.com Artikel dengan akses terbuka dibawah lisensi

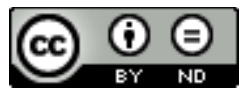

\section{Pendahuluan}

Pembelajaran daring mata kuliah bahasa Indonesia merupakan salah satu bentuk dari pembinaan dan pengembangan bahasa Indonesia, meskipun dalam situasi Pandemi Covid-19, pembelajaran harus tetap dilaksanakan walaupun dalam bentuk daring (dalam jaringan). Pembelajaran daring untuk meminimalisir Penyebaran Virus Covid-19 juga dilakukan pada mata kuliah bahasa Indonesia di Sekolah Tinggi Agama Islam Negeri (STAIN) Sultan Abdurrahman Kepulauan Riau. Model pembelajaran daring ini sangat bervariasi seperti penggunaan Aplikasi Zoom Cloud Meeting, Google Classroom, Google Meet, Video Pembelajaran, Group Whatsapp Mata Kuliah, dan lain sebagainya. Penelitian ini dilakukan pada pembelajaran daring grup whatsapp matakuliah bahasa Indonesia. Proses tanya jawab dan diskusi terhadap materi yang sedang dibahas terjadi ketika pembelajaran daring berlangsung. Penulis melihat ada beberapa deiksis yang digunakan selama proses tanya jawab dan diskusi di Grup Whatsapp Mata Kuliah bahasa Indonesia. Deiksis ini muncul pada pertanyaan dan jawaban ketika proses pembelajaran daring berlangsung sehingga penelitian ini bertujuan untuk menganalisis bentuk dan fungsi deiksis yang muncul ketika menjawab dan merespon pertanyaan tersebut. (Damayanti, 2015) mengemukakan bahwa bahasa Indonesia digunakan sangat luas di perguruan tinggi, di media massa, sastra, perangkat lunak, surat menyurat resmi, dan berbagai forum publik lainnya, sehingga dapat dikatakan bahwa bahasa Indonesia digunakan oleh semua aspek warga negara Indonesia. Ada tiga hal yang perlu diperhatikan pada fase perkembangan bahasa menurut (Herlina, 2019), yaitu: durasi, pendampingan dan keberimbangan. Sejak usia tiga tahun beberapa anak mulai dapat mengakses media sendiri (menyalakan/mematikan, menjelajah media digital, menelepon, mengirim pesan, dan lain-lain). Whatsapp ini merupakan salah satu aplikasi yang terdapat dalam media digital.

Deiksis merupakan salah satu bidang kajian pragmatik. Pragmatik adalah studi tentang hubungan antara bentuk-bentuk linguistik dan pemakai bentuk-bentuk itu (Yule, 2006). (Chaer, 2013) berpendapat bahasa itu bersifat sistematis dan sistemis. Sistematis artinya bahasa itu tersusun menurut suatu pola, tidak tersusun secara acak, tidak secara sembarangan. Sedangkan sistemis artinya bahasa itu bukan sistem tunggal, tetapi terdiri dari sub-sistem atau sistem bawahan. Subsistem itu antara lain subsistem fonologi, morfologi, sintaksis, semantik, pragmatik. Manfaat belajar bahasa melalui pragmatik ialah seseorang dapat bertutur kata tentang makna yang dimaksudkan orang, asumsi mereka, maksud atau tujuan mereka, dan jenis-jenis tindakan (sebagai contoh: 
permohonan) yang mereka perlihatkan ketika mereka sedang berbicara. Percakapan juga berhubungan dengan kegiatan berbicara. Menurut Goffmann dalam (Parera, 2014), dalam membuka dan menutup percakapan telah terdapat repertoar ritual yang sudah baku. Repertoar itu terikat pada budaya dan bervariasi dari satu masyarakat ke masyarakat lainnya. Para sosiolinguis mengidentifikasi repertoar ritual sebagai rumus bahasa yang mereka sebut dengan phatic communion. J. Laver dalam (Parera, 2014) berpendapat phatic communion berupa indeksikal dan deiktik. Indeksikal merupakan fungsi repertoar pembuka yang menyampaikan kepada pendengar informasi tentang pribadi dan status sosial pembicara. Sedangkan deiktik adalah fungsi pembuka yang merujuk kepada tempat dan waktu.

Deiktik atau Deiksis memiliki rujukan dan kata acuan yang selalu berubah-ubah, tergantung pada konteksnya. Perubahan konteks tersebut sering disebabkan perubahan dari situasi, seperti penutur dan petutur, hal ini dipaparkan Levinson dalam (Muhyidin, 2019). Sebuah kata bersifat deiksis apabila rujukannya berpindah atau berganti, tergantung siapa yang menjadi pembicara, saat dan tempat dituturkannya kata-kata itu, menurut Purwo dalam (Sebastian, Diani, \& Rahayu, 2019). Menurut Kurhartati dalam (Fitrianti, 2018) Deiksis juga dapat dilihat sebagai cara menunjukkan pada suatu hal yang berkaitan erat dengan konteks penutur, dengan demikian, deiksis dapat diartikan bentuk bahasa yang titik acuannya bergantung pada penutur.

Deiksis adalah istilah teknis (dari bahasa Yunani) untuk salah satu hal mendasar yang kita lakukan dengan tuturan (Yule, 2006). Deiksis berarti penunjukan melalui bahasa. Bentuk linguistik yang dipakai untuk menyelesaikan penunjukan disebut ungkapan deiksis. Deiksis dapat digunakan untuk menunjuk orang disebut deiksis persona, untuk menunjuk tempat disebut deiksis spasial dan untuk menunjuk waktu disebut deiksis temporal (Yule, 2006). Deiksis persona atau deiksis orang ini menerapkan tiga pembagian dasar yang dicontohkan dengan kata ganti orang pertama tunggal (saya, aku, daku), orang kedua tunggal (kamu, Anda, kau), dan orang ketiga tunggal (dia, ia, beliau), dan dalam pembahasan lainnya juga termasuk kata ganti orang pertama jamak (kita, kami), kata ganti orang kedua jamak (kalian, kamu, sekalian), kata ganti orang ketiga jamak (mereka). Deiksis spasial atau deiksis tempat memiliki hubungan antara orang dan benda yang ditunjukkan. Seperti kata di sana dan di sini. Kemudian kata keterangan tempat yang menunjukkan gerakan ke arah penutur dan gerakan menjauhi penutur. Deiksis temporal atau deiksis waktu seperti kata "sekarang" yang menunjukkan baik waktu yang berkenaan dengan saat penutur berbicara maupun saat suara penutur sedang didengar, baik waktu sekarang, masa lalu maupun masa yang akan datang dengan waktu penutur sekarang (Yule, 2006). Menurut Kaswanti Purwo dalam (Nadar, 2018) kata deiksis berasal dari kata Yunani deiktikos yaitu hal penunjukan secara langsung dan sebuah kata bersifat deiktis apabila referennya berpindah-pindah atau berganti-ganti, tergantung pada saat dan tempat dituturkannya kata itu.

Beberapa ungkapan linguistik memberikan contoh hubungan antara bahasa dengan konteks yang lebih baik bukan sekedar istilah-istilah deiksis. Istilah-istilah ini 
mencakup ungkapan-ungkapan dari kategori-kategori gramatikal yang memiliki keragaman sama banyaknya seperti kata ganti dan kata kerja, menerangkan berbagai entitas dalam konteks sosial, linguistik, atau ruang-waktu ujaran yang lebih luas, (Cummings \& Setiawati, 2007), melalui acuan pada entitas berbagai konteks dapat memperoleh makna ungkapan-ungkapan deiksis, dan untuk memahaminya perlu memperhatikan makna sebuah ujaran, seperti pada ujaran "Saya ingin pergi sekarang" mungkin tidak dapat mengetahui apa yang dimaksudkan oleh ujaran tersebut tanpa mengetahui referen kata ganti orang pertama "saya", di samping itu, menetapkan referen kata ganti ini harus memperhatikan konteks yang terdiri atas penutur ujaran ini.

Kajian Deiksis terhadap karya sastra pada sebuah novel dan skenario pembelajarannya di SMA telah dilakukan oleh Asep Muhyidin yang berjudul Deiksis dalam Novel Daun yang Jatuh Tak Pernah Membenci Angin Karya Tere Liye dan Skenario Pembelajarannya di SMA. Hasil penelitian (Muhyidin, 2019) menunjukkan ditemukan sebanyak 992 deiksis, yang terdiri atas deiksis persona sejumlah 879, deiksis ruang sejumlah 82, dan deiksis waktu sejumlah 31 buah. Kajian deiksis dalam penelitian tersebut berimplikasi terhadap pembelajaran bahasa Indonesia di SMA Kelas XII, khususnya pada pembelajaran menyunting novel. Hal ini disebabkan deiksis terkait dengan pemilihan kata dan penggunaan kalimat yang efektif pada pembelajaran bahasa Indonesia. Selain novel, kajian dan analisis deiksis juga dilakukan pada percakapan formal maupun informal Mahasiswa Pendidikan bahasa Indonesia Universitas Bengkulu, dilakukan oleh Dwiyan Sebastian et.al., dengan judul Analisis Deiksis pada Percakapan Mahasiswa Pendidikan Bahasa Indonesia Universitas Bengkulu. Hasil penelitian (Sebastian et al., 2019) yaitu deiksis yang ditemukan meliputi, deiksis persona (persona pertama tunggal, persona pertama jamak, persona kedua tunggal, persona kedua jamak, persona ketiga tunggal), deiksis ruang/tempat, deiksis waktu (lampau, sekarang, mendatang, deiksis wacana (anafora, katafora), deiksis sosial.

Kemudian Penelitian Deiksis Sosial dalam Diskusi Mahasiswa Program Studi Pendidikan Bahasa dan Sastra Indonesia Fakultas Keguruan dan Ilmu Pendidikan Universitas Ekasakti Padang juga sudah dilakukan oleh Eva Fitrianti ketika mengamati mahasiswa mempresentasikan tugas mereka dengan judul Deiksis Sosial dalam Diskusi Mahasiswa Program Studi Pendidikan Bahasa dan Sastra Indonesia Fakultas Keguruan dan Ilmu Pendidikan Universitas Eka Sakti Padang. Hasil penelitian (Fitrianti, 2018) yaitu beberapa deiksis sosial ditemukan pada mahasiswa ketika berdiskusi mempresentasikan tugas mereka seperti deiksis ucapan, jenis julukan, jenis profesi, jenis gelar, dan jenis pekerjaan. Penggunaan deiksis sosial secara tepat berhubungan dengan kesopanan. Selain itu, deiksis sosial juga dapat meningkatkan kesopanan seseorang dalam berbicara. Hubungan antara deiksis sosial dan kesopanan dapat digunakan untuk mengekspresikan makna yang sangat sopan, agak sopan, kurang sopan dan adil. Penelitian deiksis dalam wacana berita telah dilakukan oleh Pratiwi dan Lutfi berjudul Bentuk dan Fungsi Deiksis dalam Wacana Pengungsi Syria Harian Suddeutsche Zeitung. Adanya deiksis dalam wacana berita pengungsi Syria pada Suddeutsche Zeitung membantu pemahaman pembaca terhadap peristiwa yang 
diberitakan. Hasil penelitiannya terdapat empat bentuk deiksis dan fungsi deiksis, yaitu deiksis demonstratif, deiksis waktu, deiksis sosial, dan deiksis wacana. Penelitian deiksis dalam tajuk rencana telah dilakukan oleh Purwandari, et.al berjudul Bentuk dan Fungsi Deiksis dalam Tajuk Rencana pada Surat Kabar Solo Pos Edisi 2017 dan Relevansinya sebagai Bahan Ajar Pembelajaran Teks Editorial di Sekolah Menengah Atas. Hasil penelitiannya terdapat lima bentuk deiksis berupa persona, tempat atau ruang, waktu, wacana, sosial dan tajuk rencana pada Surat Kabar Solo Pos Edisi 2017 memenuhi kriteria sebagai bahan ajar pembelajaran teks editorial di sekolah menengah atas. Penelitian deiksis dalam Antologi Cerpen sudah dilakukan oleh Raihanny et.al berjudul Deiksis dalam Antologi Cerpen Pembunuh Ketujuh Karya Herman RN. Hasil penelitiannya mendeskripsikan deiksis persona, deiksis tempat, dan deiksis waktu yang ditemukan sangat beragam. Deiksis persona terdiri dari persona pertama, kedua dan ketiga, baik tunggal maupun jamak. Deiksis tempat terdiri dari deiksis tempat yang proksimal (dekat), semi-proksimal (agak jauh), maupun distal (jauh), deiksis tempat berbentuk verba dan deiksis tempat pronomina demonstratif. Deiksis waktu terdiri dari deiksis waktu yang menyatakan waktu lampau, waktu kini, waktu yang akan datang dan waktu frekuensitatif.

Penelitian deiksis pada wacana sarasehan habib telah dilakukan Riza, et.al dengan judul Deiksis pada Wacana Sarasehan Habib dengan Masyarakat. Hasil penelitian deiksis pada wacana sarasehan habib dengan masyarakat ini ditemukan bentuk-bentuk deiksis persona, spasial, temporal, wacana, sosial dan numeral. Wacana sarasehan habib terdapat ciri yang khas yaitu bentuk deiksis yang jumlahnya ribuan. Fungsi deiksis ada lima yaitu fungsi emotif. Konatif, referensial, puitik dan fatik. Bentuk deiksis yang paling dominan adalah bentuk deiksis kita. Alasan penggunaan deiksis kita adalah menghilangkan jarak sosial antara habib dengan jamaahnya, sehingga tercipta adanya rasa kesatuan di antara mereka dan pembicaraan menjadi lebih luas, santai dan lancar. Penelitian deiksis pada wacana narasi buku telah dilakukan Apu, et.al dengan judul Deiksis dalam Wacana Narasi Buku Siswa Bahasa Indonesia SMP Kelas VII Revisi 2017. Hasil penelitiannya berupa bentuk deiksis persona yang terdapat pada wacana narasi terdiri dari deiksis persona pertama saya dan kita serta deiksis persona ketiga ia, nya, mereka. Deiksis penunjuk yang terdapat dalam wacana narasi yaitu itu dan ini, dalam wacana narasi ini tidak terdapat deiksis tempat, deiksis waktu, deiksis wacana, dan deiksis sosial.

Penelitian ini dengan penelitian sebelumnya memiliki persamaan yaitu mengenai kajian deiksis dan perbedaannya terletak pada bahan yang dikaji seperti deiksis pada karya sastra berbentuk novel oleh Asep Muhyidin, deiksis pada percakapan formal dan informal mahasiswa oleh Dwiyan Sebastian et.al, deiksis sosial dalam diskusi mahasiswa oleh Eva Fitrianti, deiksis dalam wacana berita oleh Pratiwi dan Lutfi, deiksis pada tajuk rencana oleh Purwandari et.al., deiksis dalam antologi cerpen oleh Raihanny, deiksis dalam wacana sarasehan habib oleh Riza et.al., deiksis dalam wacana narasi buku siswa oleh Apu, et.al. Penelitian deiksis ini berfokus pada tuturan mahasiswa ketika pembelajaran dalam jaringan (daring) berlangsung di Grup Whatsapp 
Mata Kuliah bahasa Indonesia STAIN Sultan Abdurahman Kepulauan Riau. Konteks dan situasi tutur berkaitan dengan deiksis yang digunakan mahasiswa dalam pembelajaran daring mata kuliah bahasa Indonesia ini perlu dipahami bentuk dan fungsinya agar pembelajaran daring dapat dilaksanakan secara efektif dan maksimal sebagai salah satu bentuk dari pembinaan dan pengembangan bahasa Indonesia, meskipun dalam situasi Pandemi Covid-19. Penggunaan kajian pragmatik terutama deiksis dalam pembelajaran memiliki peran untuk menentukan hubungan antara bahasa dengan konteks dalam ujaran dan menentukan keadaan atau situasi antara penutur dengan lawan tutur pada saat berinteraksi. Penelitian ini bertujuan untuk mendeskripsikan bentuk dan fungsi deiksis Pembelajaran Daring (Dalam Jaringan) Mata Kuliah bahasa Indonesia di STAIN Sultan Abdurrahman Kepulauan Riau.

Manfaat penelitian ini membantu pengajar memahami dan membedakan fungsi deiksis persona, tempat dan waktu sesuai situasi dan kondisi yang terjadi dalam pembelajaran daring, yaitu untuk memperjelas keterangan rujukan deiksis persona, tempat dan waktu ketika penutur bertutur sesuai konteks situasi dan kondisi yang terjadi saat pembelajaran daring berlangsung.

\section{Metode Penelitian}

Metode penelitian yang digunakan adalah penelitian kualitatif, dengan bentuk deskriptif kualitatif yang dilakukan di kelas yang penulis ajar yaitu Kelas A1 berjumlah 25 mahasiswa, Kelas B2 berjumlah 19 mahasiswa Semester I Program Studi Manajemen Pendidikan Islam, kemudian Kelas A1 Semester I Program Studi Ilmu AlQur'an dan Tafsir berjumlah 16 orang dan Semester I Program Studi Akuntansi Syari'ah berjumlah 10 orang, pada bulan September - Desember 2020 di STAIN Sultan Abdurrahman Kepulauan Riau. Teknik pengumpulan data yang digunakan adalah teknik simak. Teknik keabsahan data diperoleh menggunakan triangulasi sumber proses pembelajaran daring berupa interaksi antara dosen dan mahasiswa dalam Grup Whatsapp Mata Kuliah bahasa Indonesia. Teknik analisis data yang digunakan adalah model interaktif yang terdiri dari pengumpulan data, reduksi data, penyajian data, dan conclusion drawing.

\section{Hasil dan Pembahasan}

Hasil penelitian yang ditemukan dalam pembelajaran daring berupa deiksis persona, deiksis waktu dan deiksis tempat. Deiksis persona dapat dilihat pada tuturan berikut ini:

"Maaf buk saya terkendala dengan jaringan."

"Bagaimana Infra Salsabila? Apakah bisa menerima jawaban saya?"

"Kalau kemaren memang dia kerja buk, tapi kalau hari ini saya kurang tau buk."

"Tapi saya lagi coba hubungi dia buk."

"Maaf buk mau nanya ini tugasnya kami membuat hasil pemahaman dari video pembelajaran atau dari softfile yang ibu share di WAG?" 
Pada video pembelajaran yang sama-sama telah kita tonton tadi. Terdapat kalimat dalam pengertian berfikir ilmiah ada disebut "Metode Logiko Hipotetiko Verifikatif". Jelaskan pengertian dari Metode Logiko Hipotetiko Verifikatif itu?

Kita bisa lihat bagaimana orang-orang menciptakan karyanya, apa saja yang mereka siapkan dalam menciptakan karya tersebut lalu kita jadikan orang-orang tersebut sebagai motivasi untuk menciptakan karya ilmiah kita sendiri.

Tuturan tersebut merupakan bentuk deiksis orang atau deiksis persona yang ditandai dengan penggunaan kata "saya" sebagai kata ganti orang pertama tunggal, kata "ia" dan "dia" sebagai kata ganti orang ketiga tunggal, kata "kita" dan kata "kami" sebagai kata ganti orang pertama jamak, dan kata "mereka" sebagai kata ganti orang ketiga jamak dengan konteks penutur berada dalam situasi dan kondisi Pembelajaran Daring pada Masa Pandemi Covid-19 di Grup Whatsaap Mata Kuliah bahasa Indonesia. Fungsi Deiksis Orang ini salah satunya untuk memperjelas siapa rujukan penutur, serta maksud dan maknanya. Misalnya pada Tuturan: Maaf buk saya terkendala dengan jaringan, dapat diambil maknanya bahwa penutur pada tuturan tersebut mengalami kendala jaringan dalam pembelajaran daring.

Deiksis persona atau deiksis orang ini menerapkan tiga pembagian dasar (Yule, 2006) yang dicontohkan dengan kata ganti orang pertama tunggal (saya, aku, daku), orang kedua tunggal (kamu, Anda, kau), dan orang ketiga tunggal (dia, ia, beliau) dan dalam pembahasan lainnya juga termasuk kata ganti orang pertama jamak (kita, kami), kata ganti orang kedua jamak (kalian, kamu, sekalian), kata ganti orang ketiga jamak (mereka).

Deiksis tempat dapat dilihat pada tuturan berikut:

"Sudah buk, jaringan di sini agak susah buk, saya sudah kirim."

Tuturan tersebut merupakan bentuk dari deiksis tempat atau deiksis spasial. Deiksis spasial atau deiksis tempat memiliki hubungan antara orang dan benda yang ditunjukkan. Seperti kata di sana dan di sini. Kemudian kata keterangan tempat yang menunjukkan gerakan ke arah penutur dan gerakan menjauhi penutur (Yule, 2006). Fungsi dari deiksis tempat ini yaitu untuk memperjelas keterangan tempat atau posisi penutur sesuai konteks situasi dan kondisi yang terjadi saat pembelajaran daring berlangsung. Misalnya pada tuturan: Sudah buk, jaringan di sini agak susah buk, saya sudah kirim. Penutur menjelaskan bahwa penutur sudah mengirimkan jawaban meskipun jaringan agak susah di tempat penutur.

Deiksis waktu dapat dilihat pada tuturan berikut:

"Maaf bu sebelumnya saya mengirimkan jawabannya di jam 09.27.

Tuturan tersebut merupakan bentuk deiksis waktu atau deiksis temporal. Deiksis temporal atau deiksis waktu seperti kata "sekarang" yang menunjukkan baik waktu yang berkenaan dengan saat penutur berbicara maupun saat suara penutur sedang didengar, baik waktu sekarang, masa lalu maupun masa yang akan datang dengan waktu penutur sekarang (Yule, 2006). Fungsi dari deiksis waktu ini salah satunya yaitu untuk memperjelas keterangan waktu ketika penutur bertutur sesuai konteks situasi dan kondisi yang terjadi saat pembelajaran daring berlangsung. Misalnya pada tuturan 
tersebut: Maaf bu sebelumnya saya mengirimkan jawabannya di jam 09.27. Penutur mengirimkan jawaban pada pukul 09.27 lewat dari jadual yang ditentukan karena batas pengiriman jawaban di pukul 09.25. Pembelajaran daring berlangsung mulai pukul 07.45-09.25.

Perbandingan dengan penelitian deiksis yang lainnya yaitu pada pembelajaran daring ini deiksis persona dominan lebih banyak menggunakan kata ganti saya, dia, kami, kita, mereka sebagai kata ganti orang pertama tunggal, ketiga tunggal, pertama jamak, dan ketiga jamak, dalam konteks pembelajaran daring, dan deiksis persona dominan lebih banyak muncul daripada deiksis tempat dan deiksis waktu.

\section{Kesimpulan}

Hasil penelitian yang ditemukan dalam tuturan mahasiswa selama pembelajaran daring berupa deiksis persona, deiksis waktu dan deiksis tempat. Deiksis persona dominan lebih banyak menggunakan kata ganti saya, dia, kami, kita, mereka sebagai kata ganti orang pertama tunggal, ketiga tunggal, pertama jamak, dan ketiga jamak, dalam konteks pembelajaran daring, dan deiksis persona dominan lebih banyak muncul daripada deiksis tempat dan deiksis waktu. Fungsi dari deiksis persona, tempat dan waktu ini salah satunya yaitu untuk memperjelas keterangan rujukan deiksis persona, tempat dan waktu ketika penutur bertutur sesuai konteks situasi dan kondisi yang terjadi saat pembelajaran daring berlangsung. Konsep mengenai deiksis diperlukan pengajar untuk memahami dan memperjelas rujukan tuturan mahasiswa selama proses belajar mengajar untuk kelancaran pembelajaran daring. 


\section{BIBLIOGRAFI}

Apu, Fatmaruwanti. et.al. (2019). Deiksis dalam Wacana Narasi Buku Siswa Bahasa Indonesia SMP Kelas VII Revisi 2017. Jurnal Bastra (Bahasa dan Sastra), 4(1).

Chaer, Abdul. (2013). Linguistik Umum. Jakarta: Rineka Cipta.

Cummings, Louise, \& Setiawati, Eti. (2007). Pragmatik: sebuah perspektif multidisipliner. Bandung: Pustaka Pelajar.

Damayanti, Rini. dan Tri Indrayanti. (2015). Bahasa Indonesia untuk Perguruan Tinggi. Surabaya: Victory Inti Cipta.

Fitrianti, Eva. (2018). Deiksis Sosial Dalam Diskusi Mahasiswa Program Studi Pendidikan Bahasa Dan Sastra Indonesia Fakultas Keguruan Dan Ilmu Pendidikan Universitas Ekasakti Padang. UNES Journal of Education Scienties, 2(1), 71-81.

Herlina S., Dyna. (2019). Literasi Media: Teori dan Fasilitasi. Bandung: PT Remaja Rosda Karya.

Muhyidin, Asep. (2019). Deiksis Dalam Novel Daun Yang Jatuh Tak Pernah Membenci Angin Karya Tere Liye dan Skenario Pembelajarannya di SMA. Metalingua, 17(1), 45-46.

Nadar, F. X. (2018). Pragmatik dan Penelitian Pragmatik. Yogyakarta: Graha Ilmu.

Parera, J. .. (2014). Teori Semantik. Jakarta: Penerbit Erlangga.

Pratiwi, Wirawati Adhi dan Lutfi Saksono. (2017). Bentuk dan Fungsi Deiksis dalam Wacana Pengungsi Syria Harian Suddeutsche Zeitung. Identitaet, 6(1), 1-15.

Purwandari, Meilda Maharani. et.al. (2019). Bentuk dan Fungsi Deiksis dalam Tajuk Rencana pada Surat Kabar Solo Pos Edisi 2017 dan Relevansinya sebagai Bahan Ajar Pembelajaran Teks Editorial di Sekolah Menengah Atas. Basastra; Jurnal Bahasa, Sastra dan Pengajarannya, 7(1), 186-192.

Raihanny, Sri. et.al. (2017). Deiksis dalam Antologi Cerpen Pembunuh Ketujuh Karya Herman RN. Jurnal Ilmiah Mahasiswa Jurusan PBSI, 2(4), 378-392.

Riza, Luqman Nur. et.al. (2017). Deiksis pada Wacana Sarasehan Habib dengan Masyarakat. Seloka, 6(3), 273-285.

Sebastian, Dwiyan, Diani, Irma, \& Rahayu, Ngudining. (2019). Analisis Deiksis Pada Percakapan Mahasiswa Pendidikan Bahasa Indonesia Universitas Bengkulu. Jurnal Ilmiah KORPUS, 3(2), 157-165.

Yule, George. (2006). Pragmatik (Terjemahan Indah Fajar Wahyuni). Yogyakarta: Pustaka Pelajar. 